日植病報 $53: 523-530$ (1987)

Ann. Phytopath. Soc. Japan $53: 523-530$ (1987)

\title{
Lipid Peroxidation during the Development of Pine Wilt Disease
}

\author{
Toshihiro YAMADA*
}

\begin{abstract}
Changes in the degree of lipid peroxidation and the activity of enzymes which scavenge active oxygens were investigated during the development of pine wilt disease. Current branches of 4-year-old Japanese black pine seedlings inoculated with the pine wood nematode were used as test materials. Malondialdehyde (MDA) content, an indicator of lipid peroxidation, increased in both the bark and xylem of inoculated seedling until dying of seedling. The increment of MDA content and the population growth of the nematode seem to reflect the degree of tissue deterioration. Changes in soluble protein content and peroxidase activity corresponded considerably to the change of MDA content. Peroxidase activity in the xylem increased more rapidly than that in the bark. Superoxide dismutase (SOD) activity in the xylem decreased after 4th week of inoculation. Catalase activity in the xylem decreased gradually after the inoculation. Trace of SOD activity and no catalase activity were detected in the bark. The present study suggests that damage of membranemembrane lipid peroxidation-is involved in the development of pine wilt disease.
\end{abstract}

(Received April 24, 1987)

Key words : pine wilt disease, Bursaphelenchus xylophilus, lipid peroxidation, superoxide dismutase, catalase, peroxidase.

\section{Introduction}

Active oxygens such as $\mathrm{O}_{2}^{-} \cdot$, $\mathrm{HO} \cdot{ }^{1} \mathrm{O}_{2}$ and $\mathrm{H}_{2} \mathrm{O}_{2}$ induce peroxidation of biomembrane lipids (membrane deterioration) ${ }^{15,25)}$. Peroxidation of membrane lipid may produce secondarily toxic substances, and disruption of membrane integrity occurrs ${ }^{5,10,14,26)}$.

Active oxygens also play an important role in the defense mechanism in plant desease as well as animal disease. In plant disease, it has been shown that superoxide anion generation was involved in the hypersensitive response ${ }^{11,31)}$. Increases in the degree of lipid peroxidation and free radicals were also found in the hypersensitive response ${ }^{14,16}$, 30).

On the other hand, senescence, various stresses and toxins cause the increase in the degree of lipid peroxidation and active oxygens generation ${ }^{7-10,22,23)}$. In blast-infected rice leaves, enhancement of lipid peroxidation was reported not only in incompatible interaction but also in compatible one ${ }^{19)}$.

Furthermore, active oxygens, free radicals and lipid peroxidation accelerate ethylene production $^{2,6,21)}$. Ethylene production and peroxidase activity increase during the devel-

\footnotetext{
* Kansai Branch, Forestry and Forest Products Research Institute, Kyoto 612, Japan 林業試験場
} 関西支場 
opment of the pine wilt disease caused by the pinewood nematode, Bursaphelenchus xylophilus (Steiner et Buhrer) Nickle ${ }^{20,28}$. Therefore, active oxygens and lipid peroxidation are supposed to be concerned in enhancement of ethylene production and peroxidase activity in the pine wilt disease. The present report describes the change in the degree of lipid peroxidation, and in the activity of several enzymes which scavenge active oxygens in the Japanese black pine, Pinus thunbergii Parl., inoculated with the nematode.

\section{Materials and Methods}

B. xylophilus (isolate S-10) was reared on Botrytis cinerea Pers. growing on potato dextrose agar at $25 \mathrm{C}$. Ten thousand of nematodes were inoculated onto two-year-old portion of main stem of the four-year-old seedling of the Japanese black pine growing in field on July 30,1985 . Current branches were sampled at $3,7,14,21,28,34$, and 43 days after inoculation. Three branches were sampled at each time of cutting. Each sample was separated into tissues of bark and xylem and the following measurements were made for both tissues.

Levels of malondialdehyde (MDA) were measured to determine the degree of lipid peroxidation. Ground tissues were assayed for MDA using a modified thiobarbituric acid (TBA) test ${ }^{19)}$. The concentration of MDA was calculated from its extinction coefficient of $155 \mathrm{mM}^{-1} \mathrm{~cm}^{-1}$.

Each sample $(0.4 \mathrm{~g}$ ) was homogenized in $4 \mathrm{ml}$ of $0.2 \mathrm{M}$ Tris- $\mathrm{HCl}$ buffer ( $\mathrm{pH} 7.0$ ) with seasand in a mortar, and centrifuged at $20,000 \times g$ for $1 \mathrm{hr}$. The supernatant was dialysed against $0.5 \mathrm{M}$ sucrose solution, and the inner solution was used as an crude protein solution. Protein content was measured according to the method of Lowry et $a l .{ }^{18)}$.

Crude protein solution was assayed for the activity of enzymes. Peroxidase activity was determined by the method of Yamamoto et al. using benzidine ${ }^{29)}$. Superoxide dismutase (SOD) was localized on the polyacrylamide gel as the inhibition zone of nitro blue tetrazolium (NBT) reduction in photoreduction system ${ }^{3,17}$. The gel stained for SOD activity was scanned by a spectrophotometer at $560 \mathrm{~nm}$, and SOD activity was calculated by comparing the peak area with the standard calibration. Standard calibration was prepared using SOD (from bovine blood) obtained from Sigma Chemical Co. Catalase was detected by polyacrylamide gel electrophoresis (PAGE) ${ }^{27)}$, and the activity was assayed by measuring the initial rate of disappearance of hydrogen peroxide ${ }^{4}$.

Oleoresin exudation from the cut end of current branch sampled was recorded. Nematodes were separately extracted from the tissues by the Baermann funnel technique, and counted. Pine tissues were dried at $105 \mathrm{C}$ for $24 \mathrm{hr}$, and moisture contents of the tissues were determined.

Tissue samples were fixed in formalin-acetic acid-alcohol (FAA), dehydrated in alcohol series, and embedded in paraffin. Preparates of sections of 20 micrometers in thickness were made using cellophane tape and stained with safranin-fast green to observe microscopically ${ }^{24)}$. 


\section{Results and Discussion}

MDA content of the bark (including cortex and phloem) of current branches increased significantly 2 weeks after inoculation and then continued to increase (Fig. 1). MDA content of the xylem showed similar change to that of the bark.

Soluble protein content of the bark increased obviously 2 weeks after inoculation and reached the peak 4 weeks after inoculation (Fig. 2). Protein content of the xylem also increased.

Peroxidase activity increased rapidly in the bark and xylem 4 weeks and 2 weeks after inoculation, respectively (Fig. 3). The highest activities were found 5 weeks after inoculation in both the bark and xylem.

MDA content, protein content and peroxidase activity decreased 6 weeks after inoculation. These decrease were supposed to be due to dying of seedlings.

Three bands of SOD activity were detected in the xylem by PAGE. Traces of SOD activity (mobility of the enzymes on the gel were the same as those in the xylem) were detected in the bark. SOD activity in the xylem decreased after 4th week of inoculation (Table 1).

Catalase activity was detected in the xylem by PAGE, but not in the bark. Catalase activity in the xylem decreased gradually after inoculation (Table 2).

Samples collected from seedlings which were inoculated but survived during the experiment were also examined until 3 weeks after inoculation. In these seedlings,

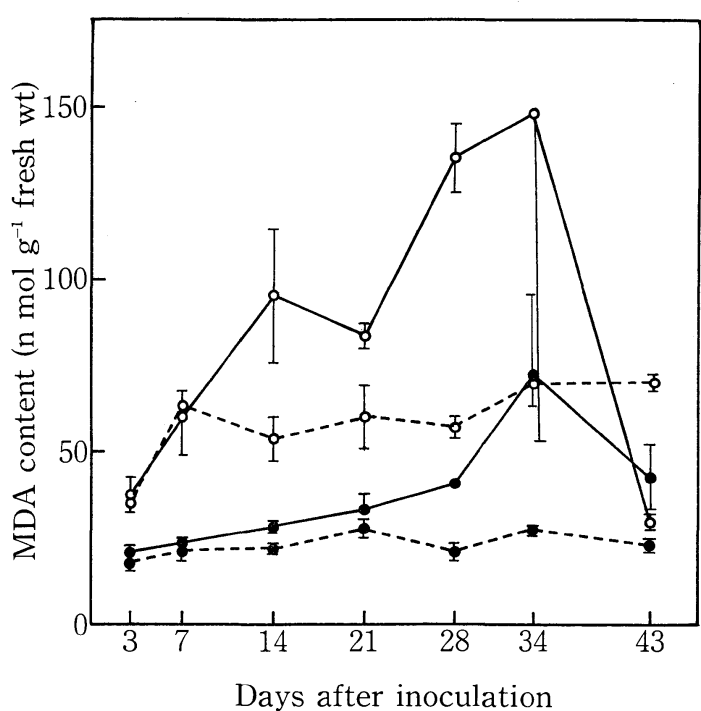

Fig. 1. Changes in malondialdehyde (MDA) content of the bark (O) and xylem (O) of the Japanese black pine inoculated with Bursaphelenchus xylophilus. Standard deviations are shown by bars. - - inoculated; - - , control. degree of lipid peroxidation, protein content and peroxidase activity increased. While, catalase activity decreased.

Destruction of epithelial cells surrounding resin canals of the bark was observed 3 days after inoculation (Plate IA, B). Two weeks after inoculation, epithelial cells of the xylem were destroyed, xylem parenchyma cells necrosed and epithelial cells of the bark were destroyed increasingly (Plate IC). Destruction of bark tissue and cambial zone related to the presence of nematodes was observed at 2 weeks (Plate ID). Four weeks after inoculation, tissue deterioration and cambium destruction became appreciable in both the bark and xylem (Plate IE). Six weeks after inoculation, tissue necrosed completely. 


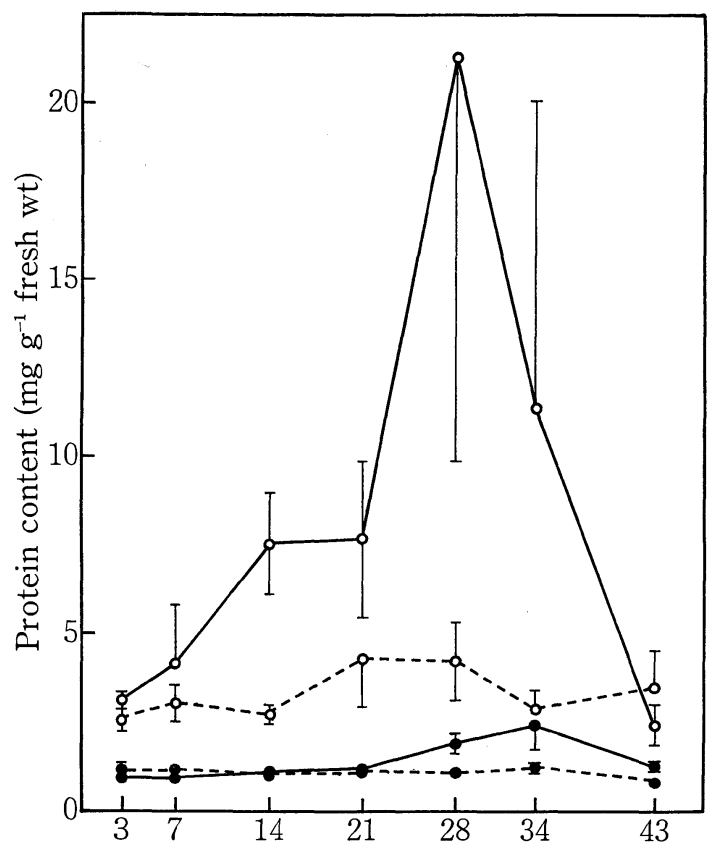

Days after inoculation

Fig. 2. Changes in protein content of the bark (O) and xylem (O) of the Japanese black pine inoculated with Bursaphelenchus xylophilus. Standard deviations are shown by bars. —, inoculated; --- , control.

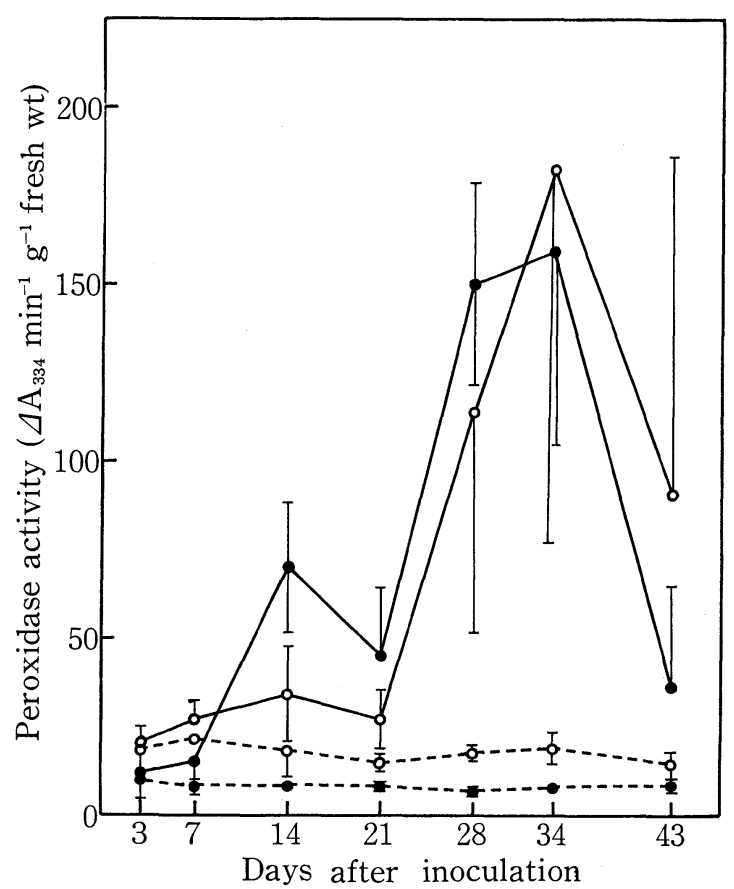

Fig. 3. Changes in the activity of peroxidase in the bark $(O)$ and xylem $(O)$ of the Japanese black pine inoculated with Bursaphelenchus xylophilus. Standard deviations are shown by bars. inoculated; ---, control.

Table 1. Changes in SOD activity in the xylem of Japanese black pine inoculated with Bursaphelenchus xylophilus a)

\begin{tabular}{l|c|c|c|c|c|c|c}
\hline \hline & \multicolumn{7}{|c}{ Days after inoculation } \\
\cline { 2 - 7 } & 3 & 7 & 14 & 21 & 28 & 34 & 43 \\
\hline & \multicolumn{8}{|c|}{ units/g fresh weight } \\
Inoculated & 40 & 52 & 53 & 54 & $20^{* \mathrm{~b})}$ & $11^{*}$ & $8^{*}$ \\
Control & 38 & 49 & 33 & 70 & 46 & 78 & 47 \\
\hline
\end{tabular}

a) Traces of SOD activity were detected in bark tissues.

b) Asterisks indicate the significant difference to control at the level of $5 \%$.

Two-year-old leaves browned slightly 3 weeks, and conspicuously 4 weeks after inoculation. Current leaves remained green until 5 weeks after inoculation.

Oleoresin exudation from cut end decreased 2 weeks after inoculation and it became slight 3 weeks after. Seedlings which did not die also showed the decrease of oleoresin exudation until 3 weeks after inoculation.

Population of the nematode and moisture content were investigated as indicators of disease development. Population of the nematode in the tissue began to increase 2 weeks after inoculation and continued to increase during the experiment (Fig. 4). Mois- 


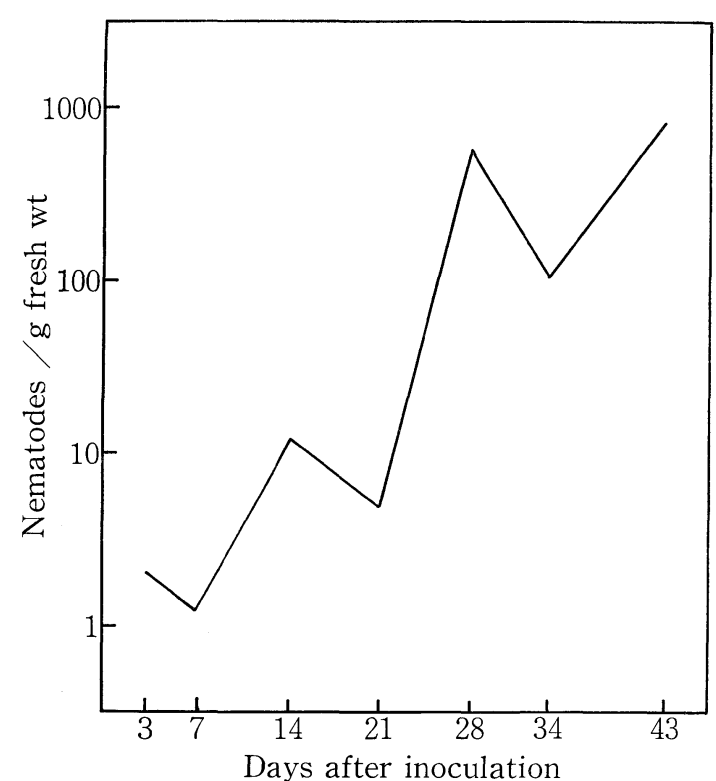

Fig. 4. Population growth of Bursaphelenchus xylophilus in nematode-inoculated Japanese black pine.

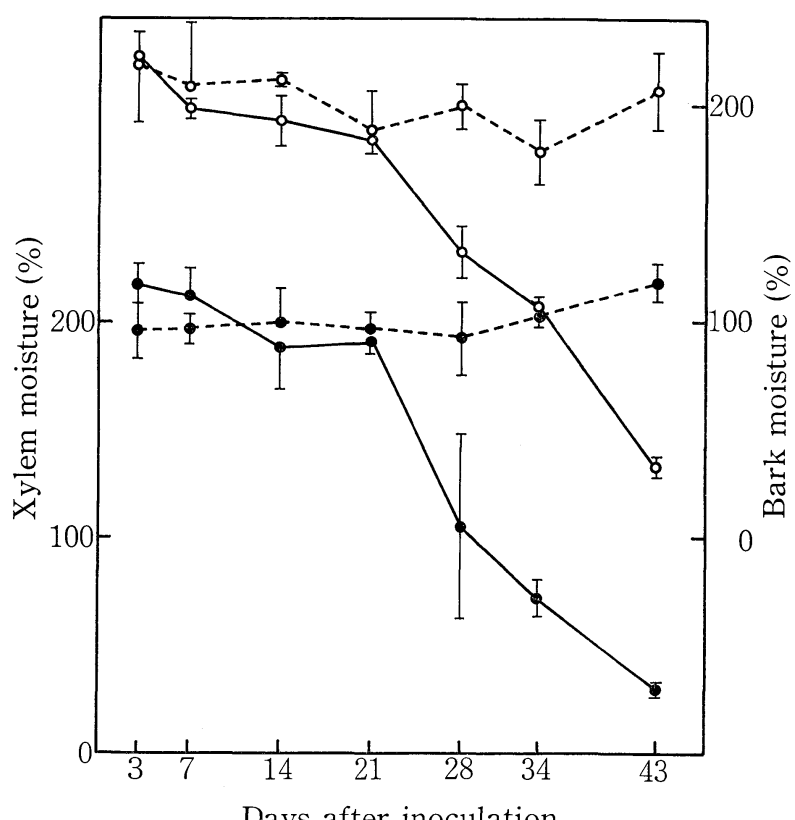

Days after inoculation

Fig. 5. Changes in moisture content of the bark (O) and xylem (O) of the Japanese black pine inoculated with Bursaphelenchus xylophilus. Standard deviations are shown by bars. - inoculated; ---, control.

Table 2. Changes in catalase activity in the xylem of Japanese black pine inoculated with Bursaphelenchus xylophilus a)

\begin{tabular}{l|c|c|c|c|c|c|c}
\hline & \multicolumn{7}{|c}{ Days after inoculation } \\
\cline { 2 - 6 } & 3 & 7 & 14 & 21 & 28 & 34 & 43 \\
\hline & \multicolumn{10}{|c|}{$-\Delta \mathrm{A}_{240} / \mathrm{min} / \mathrm{g}$ fresh weight } \\
Inoculated & 0.63 & 0.46 & 0.26 & $\left.0.22^{* \mathrm{~b}}\right)$ & $0.20^{*}$ & $0.18^{*}$ & $0.18^{*}$ \\
Control & 0.60 & 0.53 & 0.42 & 0.48 & 0.51 & 0.53 & 0.69 \\
\hline
\end{tabular}

a) Catalase activity was not detected in bark tissues.

b) Asterisks indicate the significant difference to control at the level of $5 \%$.

ture content of the tissue decreased significantly 4 weeks after inoculation in both the bark and xylem (Fig. 5). Disease appears to advance considerably 4 weeks after inoculation.

Abnormality of oleoresin exudation which is a relatively early phenomenon in the development of pine wilt desease was observed at the same time (2 weeks after inoculation) as significant increment of the degree of lipid peroxidation in the bark was observed. From the results of anatomical observation and measurement of MDA content, the increment of the degree of lipid peroxidation seems to reflect the degree of tissue deterioration. Tissue deterioration by nematode infection was also observed in seedlings which did not die (Plate IF). This result corresponds to the smaller incre- 
ment of the degree of lipid peroxidation in these seedlings.

Lipid peroxidation was thought to relate closely to the damage of cells, $i$. e., deterioration of membrane systems ${ }^{5,10,14)}$. The results of this experiment suggest that damage of membrane is involved in the development of pine wilt disease induced by the nematode.

Changes in peroxidase activity and protein content corresponded considerably to the change of the degree of lipid peroxidation. Increments of MDA content, protein content and peroxidase activity are supposed not to originate from the nematode but to be due to the reaction of the pine seedling, because they decreased 6 weeks after inoculation when the nematode population reached the maximum.

Active oxygens are scavenged by superoxide dismutase, catalase and peroxidase using a variety of reductants available to the cell. However, the phenomenon that pattern of the change in peroxidase activity differs from those of the change in SOD and catalase activities is known in several plants which are infected or suffer stress ${ }^{19,23}$. This phenomenon suggests that the role of peroxidase in lipid peroxidation is different from that of SOD and catalase. Peroxidase is thought to catalyze $\mathrm{O}_{2}{ }^{-} \cdot$ and $\mathrm{H}_{2} \mathrm{O}_{2}$ generation through oxidation of $\mathrm{NAD}(\mathrm{P}) \mathrm{H}$ and cause consequently ethylene production ${ }^{1,12,13)}$. It is possible that increment of peroxidase activity concerns with the increment of the degree of lipid peroxidation and of superoxide production.

The author is grateful to Dr. H. Tamura, Kansai Branch, Forestry and Forest Products Research Institute, for his advice and critical reading of this manuscript.

\section{Literature cited}

1. Albert, F. G., Bennett, L. W. and Anderson, A. J. (1986). Can. J. Bot. 64: 573-578.

2. Beauchamp, C. and Fridovich, I. (1970). J. Biol. Chem. $245: 4641-4646$.

3. Beauchamp, C. and Fridovich, I. (1971). Anal. Biochem. 44:276-287.

4. Beers, R. F., Jr. and Sizer, I. W. (1952). J. Biol. Chem. $195: 133-140$.

5. Bidlack, W. R. and Tappel, A. L. (1973). Lipids $8: 177-182$.

6. Bousquet, J.-F. and Thimann, K. V. (1984). Proc. Natl. Acad. Sci. USA 81 : 1724-1727.

7. Chowdhury, S. R. and Choudhuri, M. A. (1985). Physiol. Plant. $65: 503-507$.

8. Daub, M. E. (1982). Plant Physiol. $69: 1361-1364$.

9. Daub, M. E. and Hangarter, R. P. (1983). Ibid. $73: 855-857$.

10. Dhindsa, R. S., Plumb-Dhindsa, P. and Thorpe, T. A. (1981). J. Exp. Bot. 32 : 93-101.

11. Doke, N. (1983). Physiol. Plant Path. $23: 345-357$.

12. Elstner, E. F. and Heupel, A. (1976). Planta $130: 175-180$.

13. Gross, G. G., Janse, C. and Elstner, E. F. (1977). Ibid. $136: 271-276$.

14. Kato, S. and Misawa, T. (1976). Ann. Phytopath. Soc. Japan $42: 472-480$.

15. Kellogg, E. W., III and Fridovich, I. (1975). J. Biol. Chem. $250: 8812-8817$.

16. Keppler, L. D. and Novacky, A. (1986). Phytopathology $76: 104-108$.

17. Laemmli, U. K. (1970). Nature $227: 680-685$.

18. Lowry, O. H., Rosebrough, N. J., Farr, A. L. and Randall, R. J. (1951). J. Biol. Chem. 193 : 26: 275 .

19. Matsuyama, N. (1983). Ann. Phytopath. Soc. Japan $49: 270-273$.

20. Mori, T. and Inoue, T. (1986). J. Jpn. For. Soc. $68: 43-50$.

21. Parups, E. V. (1984). Physiol. Plant. $60: 149-153$.

22. Pauls, K. P. and Thompson, J. E. (1980). Nature $283: 504-506$.

23. Pauls, K. P. and Thompson, J. E. (1984). Plant Physiol. $75: 1152-1157$.

24. Saho, H. (1974). Trans. mycol. Soc. Japan $15: 266-268$. 
25. Sakai, T., Kondo, N. and Sugahara, K. (1983). Physiol. Plant. 59 : 28-34.

26. Sekizawa, Y. (1982). Proceedings of the meeting on Physiological and Biochemical Plant Pathology in Japan pp. 87-96.

27. Woodbury, W., Spencer, A. K. and Stahmann, M. A. (1971). Anal. Biochem. 44 : 301-305.

28. Yamada, T., Mineo, K. and Suzuki, K. (1984). Trans. 95th Ann. Meet. Jpn. For. Soc. : 469-470.

29. Yamamoto, H., Hokin, H. and Tani, T. (1978). Phytopath. Z. 91 : 193-202.

30. Yamamoto, H. and Tani, T. (1986). J. Phytopathology $116: 329-337$.

31. Zacheo, G. and Zacheo, T. B. (1985). Phytopath. medit. $24: 274-276$.

\section{和 文 摘 要}

\section{山田利博 : マツ材線虫病の進展過程における脂質過酸化}

4 年生クロマツの主軸にマツノザイセンチュウを接種し, 枯損過程に拉けるクロマツ組織の脂質過酸化の程 度の変化および活性酸素の消去に関与する酵素の活性の変化を当年生枝について調べた。脂質過酸化の指標で あるマロンジアルデヒド (MDA) 濃度は樹皮, 木部共, 接種後次第に増大した後, 枯死に伴い低下した。MDA 濃度の増大は解剖観察でみた組織の破壊, 変性の大きさ执よび線虫の増殖と対応していた。可溶性タンパク質 含量および樹皮のペルオキシダーゼ活性はMDA 濃度と似た变化を示したが，木部のペルオキシダーゼ活性は 樹皮のそれよりも早く増大した。木部のスーパーオキシドディスムターゼ（SOD）活性は接種後 4 週間目から 低下し, 木部のカタラーゼ活性は接種後次第に低下した。樹皮には SOD 活性は殆ど，またカタラーゼ活性は まったく認められなかった。材線虫病の進展の過程に膜の損傷一脂質過酸化一が含まれることが示唆される。

\section{Explanation of plate}

\section{Plate I}

Histopathology of the Japanese black pine inoculated with Bursaphelenchus xylophilus. Arrows indicate nematodes.

A. Destruction of epithelial cells surrounding resin canals of the bark observed 3 days after inoculation.

B. Normal epithelial cells of the bark.

C. Destruction of epithelial cells surrounding resin canals of the xylem and necrosis of xylem parenchyma cells observed 2 weeks after inoculation.

D. Destruction of the bark tissue and cavities at cambium observed 2 weeks after inoculation.

E. Advanced destruction of bark tissue at 4 th week.

F. Damage of the bark and cambium in the infected seedling which survived during the experiment.

Abbreviations: c, cavity; e, epithelial cell; $\mathrm{p}$, parenchyma cell; $r$, resin canal 
Plate I
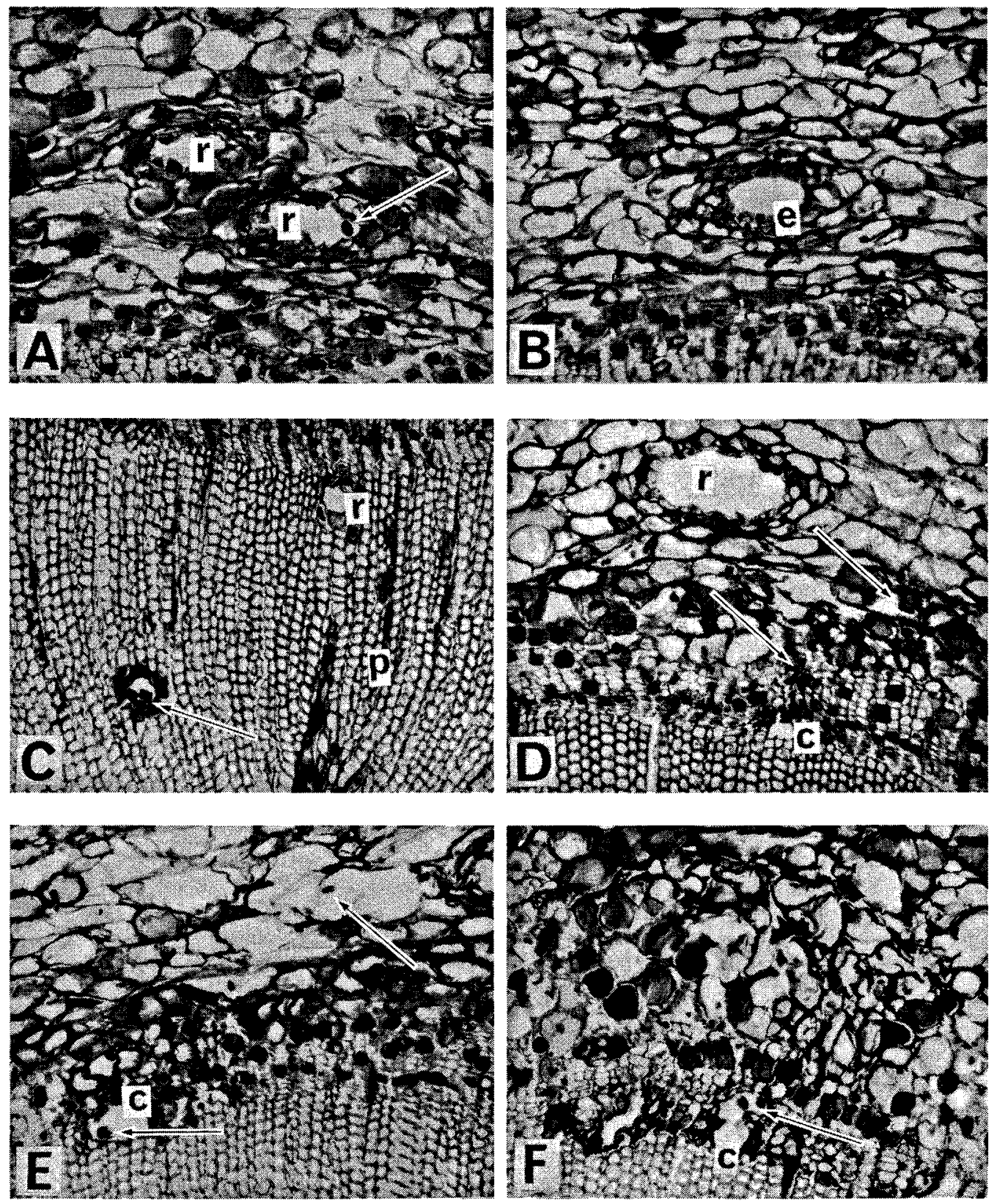